\title{
Does the Moment of Fiber Post Cutting Influence on the Retention to Root Dentin?
}

Marcela G. Borges ${ }^{1}$, André L. Faria-e-Silva ${ }^{2}$, Paulo C. F. Santos-Filho', Fernanda P. Silva', Luis R. M. Martins ${ }^{3}$, Murilo de Sousa Menezes ${ }^{1}$
'Department of Operative Dentistry and Dental Materials, Dental School, UFU - Federal University of Uberlândia, Uberlândia, MG, Brazil ${ }^{2}$ Department of Dentistry, School of Dentistry, UFS - Federal University of Sergipe, Aracaju, SE, Brazil. ${ }^{3}$ Department of Restorative Dentistry, Piracicaba Dental School, UNICAMP - University of Campinas, Piracicaba, SP, Brazil

Correspondence: Murilo de Sousa Menezes, Avenida Pará, 1720, Bloco 4LA, $3^{\circ}$ Piso, Sala 42, Campus Umuarama, 38405320 Uberlândia, MG, Brasil. Tel:+55-34-3225-8106. e-mail: murilosmenezes@yahoo.com.br

Key Words: dental bonding, resin cements, post and core technique.

\section{Introduction}

Fiber posts are commonly used to restore endodontically treated teeth when the coronal remains are unable to retain the restoration (1). These post systems present biomechanical properties similar to dentin (2), leading to a more homogeneous stress distribution than metal posts (3) and thus decreasing the risk of root fracture (4). The use of these glass fiber posts may also enhance aesthetic restorations and reduce the time required to finalize the restoration due mainly to the elimination of laboratory procedures (5). These effects are attributed to the fact that pre-fabricated posts are used; thus, the restorative procedures, including direct restorations, can be performed immediately after cementation of the post (6).

The pre-fabricated posts are available in standardized lengths and require partial sectioning to the coronal portion to adjust the clinical condition. Post sectioning can be performed prior to post insertion into the root canal, immediately after post cementation or after core/restoration build-up. Sectioning of cemented posts may generate stress via bur vibrations on the bonding interface between the luting agent and dentin. This stress can reduce the bond strength or promote areas of debonding, compromising the longevity of the post-retained restoration. These deleterious effects mainly occur when post sectioning is performed immediately after post cementation. Since cement setting is mainly activated by chemical initiation during the post cementation (7), the resin cements usually exhibit a low degree of conversion immediately after the cementation and thus reduce the bond strength to dentin (8). In contrast, when post sectioning is performed after the core build-up, the resin cement exhibits an increased degree of conversion. Furthermore, the core that is bonded to the remaining coronal dentin aids in dissipation of the stress generated by bur vibrations.

Additionally, it is reasonable to assume that the interaction between luting agents and dentin may also exacerbate the possible deleterious effects of stress caused by post sectioning. During the past several years, resin cements have been used as an adhesive system for luting fiber posts to root canals. More recently, self-adhesive resin cements (SARCs) were introduced to facilitate luting procedures (9). The bonding mechanism of SARCs is attributed to both a chemical reaction between phosphate methacrylates and hydroxyapatite as well as the infiltration of these materials into the tooth tissues (10). Various studies have demonstrated that SARCs exhibit a more stable bonding interface compared with regular resin cements (11).

Thus, the aim of this study was to evaluate the effect of the moment of post cutting on its retention to root canal when cemented with regular or self-adhesive resin cement. The hypotheses tested were: (I) the moment when post cutting occurs does not affect the bond strength of the fiber post to the root canal; and (II) the type of resin 
cement (regular or self-adhesive) does not influence on the retention of posts cut at different moments.

\section{Material and Methods}

\section{Study Design}

This in vitro investigation was conducted using a $2 \times 3$ factorial study design to evaluate the factors "moment of fiber post cutting" in three levels (before the luting procedure, immediately after post luting or after resin core build-up) and "adhesive luting agents" in two levels. The evaluated luting agents included the regular resin cement RelyX ARC (3M ESPE, St. Paul, MN, USA) and the self-adhesive resin cement RelyX Unicem (3M ESPE). The bond strengths of the fiber posts to the root canals of bovine incisors were evaluated by push-out testing $(n=10)$. The experimental design is illustrated in Figure 1.

\section{Sample Preparation}

Sixty bovine incisor roots with similar dimensions and shapes were chosen for this study. Coronal portions of the teeth were sectioned $15.0 \mathrm{~mm}$ above the root apex, using a diamond double-faced disk (KG Sorensen, Barueri, SP,

$\vec{s}$ Brazil) mounted in a slow-speed hand-piece that was cooled $\approx$ with an air/water spray. The root canal was instrumented in its full extension using \#2 and \#3 Gates Glidden drills (Dentsply Maillefer, Ballaigues, Switzerland). The \#4 drill was used exclusively in the cervical third of the root canal. Following, the canals were rinsed with $1 \%$ sodium hypochlorite solution (Asfer; Industrial Química, São Paulo, $\mathrm{SP}$, Brazil). Instrumented root canals were obturated with gutta-percha cones and Sealer-26 resin sealer (Dentsply Ind. e Com. LTDA, Petrópolis, RJ, Brazil) using the lateral condensation technique.

Post-hole spaces $10 \mathrm{~mm}$ deep were prepared using \#4 largo drills followed by burs provided by the post manufacturer (White Post DC3; FGM, Joinvile, SC, Brazil). Then, each root was embedded in a polystyrene resin cylinder (Cristal; Piracicaba, SP, Brazil) $2 \mathrm{~mm}$ below the

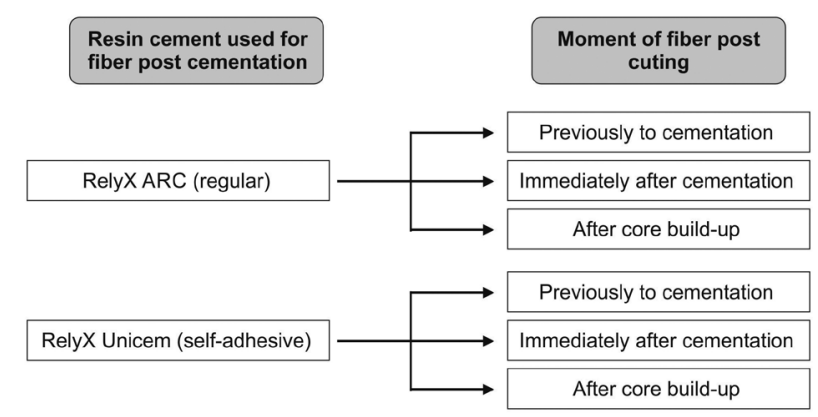

Figure 1. Experimental design. cervical limit and the periodontal ligament was simulated. For this purpose, the external surfaces of the root remainders were dipped in melted wax, resulting in a 0.2to $0.3-\mathrm{mm}$ thick wax layer. Then, the wax-covered roots were included in the acrylic resin cylinders. Following resin polymerization, the roots were removed from the cylinder and wax was removed from the root surface, creating a space in the resin cylinder. The polyether impression material (Impregum Soft; 3M ESPE) was mixed and placed in the space created in the resin cylinder. The tooth was re-inserted into the cylinder, and the excess material was removed with a scalpel blade (12).

\section{Post Cutting and Cementation}

Twenty posts ( $21 \mathrm{~mm}$ long) were cut $5 \mathrm{~mm}$ below the upper side of the post prior to the luting procedure using a \#2200 diamond bur (KG Sorensen) operated by a highspeed hand-piece using copious water spray, whereas the other 40 posts had the original dimensions maintained. Prior to cementation, the fiber posts were etched with 24\% hydrogen peroxide for $1 \mathrm{~min}$, rinsed with distilled water and air-dried (13). A layer of silane coupling agent Prosil (FGM) was applied on the etched surface of post and gently air-dried after $60 \mathrm{~s}$. The Scotchbond MultiPurpose Plus adhesive system (3M ESPE) was applied over the post surface and light-cured for $20 \mathrm{~s}$. The fiber post was cemented into the root canal using the regular resin cement RelyX ARC (ARC; 3M ESPE) associated with the Scotchbond Multipurpose Plus adhesive system or a selfadhesive cement RelyX Unicem (UNI; 3M ESPE) associated with one of the protocols explained below.

RelyX ARC: The intraradicular dentin was etched with $37 \%$ phosphoric acid for $15 \mathrm{~s}$ and rinsed. The water excess was removed with absorbent paper points. The Scotchbond Multipurpose Plus (3M ESPE) activator was applied into the root canal with a microbrush of compatible size and air-dried for $5 \mathrm{~s}$. Afterwards, the primer followed by the catalyst were applied and air-dried. The resin cement was placed over the post, and the post/cement was inserted into the root canal and light-cured for $40 \mathrm{~s}$ after removal of the excess. After $5 \mathrm{~min}$, the resin cement was lightcured for $80 \mathrm{~s}$.

RekyX Unicem: The root canal walls were rinsed with water using a syringe and then gently dried with absorbent paper points. The self-adhesive cement RelyX Unicem (3M ESPE) was mixed and placed over the posts, which were inserted into the root canal using light pressure. The luting material excess was removed and light activation was performed for $40 \mathrm{~s}$. After $5 \mathrm{~min}$, the resin cement was light-cured for $80 \mathrm{~s}$.

All light activations were performed using a LED light-curing unit (Radii Cal, SDI, Bayswater, Victoria, 
Australia) with $800 \mathrm{~mW} / \mathrm{cm}^{2}$ irradiance. Immediately after cementation, 20 posts were cut $6 \mathrm{~mm}$ above the root using a previously described bur. For the other 20 samples, a 6-mm-high core was made using Filtek Z-350 composite (3M ESPE) before the cutting procedure. To standardize the core, a matrix was designed using BIO-CAD software (Computer Assisted Desing; Rhino 3D, Rhinoceros, USA). A prototypal resin with the dimensions of the designed cores (6 $\mathrm{mm}$ high) was created and used to obtain acetate matrixes. The fiber posts were sectioned to the same level of the resin core.

\section{Push-Out Testing}

After storage for $24 \mathrm{~h}$, each root was removed from the resin cylinder and sectioned in 1-mm-thick 6 slabs perpendicular to its long axis using a slow-speed diamond saw (Isomet 1000; Buehler, Lake Bluff, IL, USA). The slabs were analyzed using optical microscopy at $40 x$ magnification (Mitutoyo, Kanagawa, Japan) to measure

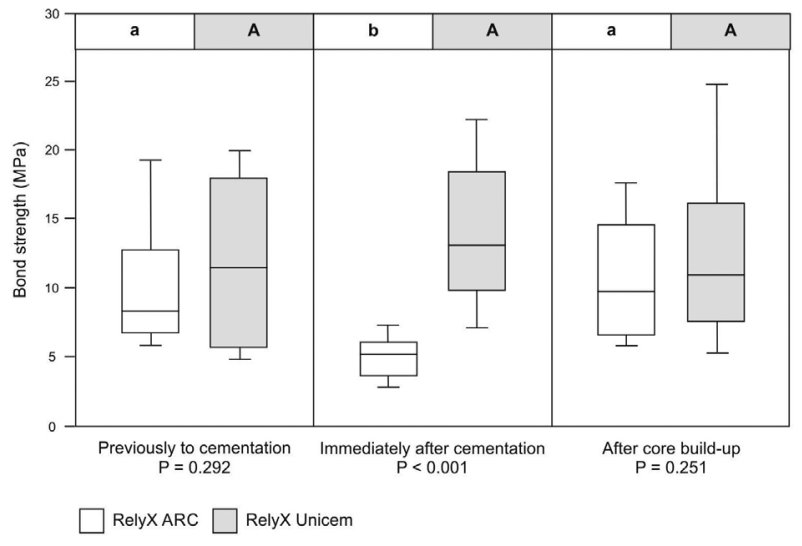

Figure 2. Push-out bond strength results. Distinct letters (lowercase letters for RelyX ARC; capital letters for RelyX Unicem) indicate statistically significant difference among the moments of fiber post cutting $(p<0.05)$. The $p$-values for comparison between cement at each moment of fiber post cutting are indicated. both major and minor post diameters in millimeters and to identify potential defects caused by cutting. Samples with defects were excluded. Each slab was positioned in a pushout jig and subjected to a compressive load $(0.5 \mathrm{~mm} / \mathrm{min})$ in a mechanical testing machine (EMIC DL 2000; EMIC, São José dos Pinhais, PR, Brazil) until the post was dislodged. The bond strength value for each slab was calculated in $\mathrm{MPa}$, and the average values of all slabs for each root were used in the statistical analysis. Data were statistically analyzed using two-way ANOVA (resin cement $x$ moment of post cutting) and Tukey's post hoc test $(\alpha=0.05)$.

\section{Results}

Values were considered for analysis regardless of root thirds because no significant differences were observed between the root regions for any experimental condition (Table 1). Significant effects were detected for the "resin cement" factor $(p<0.001)$ and the interaction between the factors ( $p=0.021)$ but not for the factor "moment of post cutting" ( $p=0.258)$. The results are displayed in Figure 2 . For RelyX Unicem, no difference was observed between the moments of post cutting. In contrast, post cutting immediately after cementation resulted in the lowest bond strength values when RelyX ARC was used, whereas no differences were observed for other post cutting moments. Bond strength differences between the resin cements were only observed for post cutting immediately after fiber post cementation, whereas RelyX Unicem exhibited the highest values.

\section{Discussion}

Despite the advantages of using pre-fabricated posts to extensively restore damaged teeth, partial cut of the coronal portion of the post is necessary to allow the buildup of the core restoration moment of post cutting on the bond strength of the fiber post to the root canal. In the present study, fiber post cutting immediately after post cementation resulted in reduced bond strength values when compared with other post cutting moments only when the post was luted using the regular resin cement RelyX ARC. Thus, the study hypotheses (I - effect of moment of post cutting, and II - effect of resin cement type) were rejected.

Fiber postsare commonly luted to root canals using dual-cured resin cements that are either associated or not with adhesive systems.
Table 1. Means $(95 \% \mathrm{Cl})$ of push-out bond strength in each root third

\begin{tabular}{lcccc}
\hline \multirow{2}{*}{ Resin cement } & Fiber post-cutting moment & \multicolumn{3}{c}{ Root third } \\
\cline { 3 - 5 } & & Cervical & Middle & Apical \\
\hline \multirow{2}{*}{ RelyX ARC } & Previously to cementation & $10.7(6.3-15.2)$ & $10.1(5.8-14.4)$ & $12.3(6.9-17.7)$ \\
& Immediately after cementation & $4.5(3.3-5.7)$ & $4.0(2.4-5.6)$ & $8.6(6.4-10.8)$ \\
RelyX Unicem & Immediately after cementation & $13.2(9.4-17.0)$ & $15.3(11.6-19.1)$ & $13.7(8.2-18.5)$ \\
& Previously to cementation & $13.4(8.0-18.8)$ & $13.7(8.9-18.6)$ & $11.8(7.6-16.0)$ \\
& After core build-up & $11.9(8.5-15.2)$ & $11.6(6.6-16.6)$ & $14.6(7.4-21.9)$ \\
\hline
\end{tabular}


The use of dual-cured luting agents is preferable in this procedure to achieve proper cement polymerization along the entire root canal space and to obtain an initial stabilization of the fiber post (14). Once the chemically activated reaction is slowed, light activation of the cement promotes the polymerization of the cement in more cervical regions, thereby establishing post retention in the first minutes after post cementation $(10,15,16)$. However, even using translucent fiber posts, a significant reduction in light intensity occurs in the deepest areas of the root canal, and only the slower chemically activated polymerization reaction occurs $(17,18)$. Thus, reduced mechanical strength of the cement and decreased bonding to the dentin root canal is evident, particularly in the early stages after cementation procedures (19).

The presence of areas of resin cement in deeper regions of root canals in the initial minutes following the fiber post cementation can explain the reduced bond strength observed for post cutting immediately after cementation with RelyX ARC. The use of diamond burs to cut the post vibrates the fiber post and may induce stress in the bonding interface, thereby reducing the bond strength. In this scenario, it is reasonable to hypothesize that the cervical region, which exhibits increased polymerization, acts as a fulcrum; thus, the stress is transmitted to the poorly polymerized deeper areas of the root canal. Since a large number of failures in the adhesive procedure is observed in the apical region of the root canal when adhesive systems are used, debonding areas may appear and propagate the defect through the bonding interface $(20,21)$. Therefore, bond strength is reduced throughout the entire bonding interface without differences between the root thirds. In contrast, when the post was cut after core building up, the bond strength values of posts luted with RelyX ARC were similar to those observed when the fiber post was cut prior to cementation. The time that elapsed between the light activation and the core build-up permits increased cement polymerization (10), thereby increasing the bonding stability. In addition, the core reconstruction in the dental remnant can potentially increase the post stabilization.

An important finding of this study was that the moment of post cutting did not affect the bond strength when the self-adhesive resin cement RelyX Unicem was used, compared with RelyX ARC. In contrast to regular resin cements, the main bonding mechanism of self-adhesive cements involves chemical chelation between functional acid methacrylates and calcium from tooth tissues (10). It could be hypothesized that chemical bonding produced by these materials results in a more stable bonding interface. A previous study demonstrated that self-adhesive resin cements support mechanical stress better than conventional resin cements (9).
Within the limitations of this in vitro study, the results indicate that the moment of fiber post cutting can reduce the retention of glass fiber posts to root canal, whereas this reduction appears to be material-dependent. However, it is important to emphasize that the immediate bond strengths of only two resin cements were evaluated. Further studies with additional resin cements and aged samples are required to confirm these findings.

\section{Resumo}

Apesar das diversas vantagens associadas aos pinos de fibra de vidro pré-fabricados, o corte da sua porção coronária deve ser realizado para permitir seu uso em algumas situações clínicas. Entretanto, o corte do pino cimentado pode gerar tensões na interface adesiva e afetar a resistência de união. 0 objetivo deste estudo foi avaliar o efeito do momento do corte do pino na resistência de união ao canal radicular. Sessenta raizes de incisivos bovinos foram incluidas em cilindros de resina com simulação do ligamento periodontal. Pinos de fibra de vidro foram cimentados utilizando um cimento resinoso convencional RelyX ARC (3M ESPE) ou autoadesivo RelyX Unicem (3M ESPE). Os pinos foram cortados previamente à cimentação, imediatamente após a cimentação, ou após a reconstrução do núcleo de preenchimento $(n=10)$. Após o armazenamento por $24 h$, as amostras foram seccionadas e submetidas ao ensaio de cisalhamento por extrusão utilizando máquina de ensaio mecânico (EMIC DL 2000). Os dados foram analisados por ANOVA dois fatores (cimento resinoso $x$ momento do corte do pino) e teste de Tukey $(\alpha=0,05)$. 0 momento do corte do pino de fibra de vidro não afetou a resistência de união quando o RelyX Unicem foi utilizado. No entanto, o corte do pino imediatamente após a cimentação reduziu os valores de resistência de união quando o RelyX ARC foi utilizado. Em conclusão, o momento do corte do pino pode afetar a resistência de união ao canal radicular quando o cimento resinoso convencional for utilizado.

\section{Acknowledgements}

This study received financial support from FAPEMIG (grant 2014-SAU027).

\section{References}

1. Ferrari M, Vichi A, Fadda GM, Cagidiaco MC, Tay FR, Breschi L, et al.. A randomized controlled trial of endodontically treated and restored premolars. J Dent Res 2012;91(7 Suppl):72S-78S.

2. Silva NR, Raposo LH, Versluis A, Fernandes-Neto AJ, Soares CJ. The effect of post, core, crown type, and ferrule presence on the biomechanical behavior of endodontically treated bovine anterior teeth. J Prosthet Dent 2010;104:306-317.

3. Coelho CS, Biffi JC, Silva GR, Abrahao A, Campos RE, Soares CJ. Finite element analysis of weakened roots restored with composite resin and posts. Dent Mat J 2009;28:671-678.

4. Santos AF, Meira JB, Tanaka CB, Xavier TA, Ballester RY, Lima RG, et al.. Can fiber posts increase root stresses and reduce fracture? J Dent Res 2010;89:587-591.

5. Lamichhane $A, X u C$, Zhang FQ. Dental fiber-post resin base material: a review. J Adv Prosthodont 2014;6:60-65.

6. Schwartz RS, Robbins JW. Post placement and restoration of endodontically treated teeth: a literature review. J Endod 2004;30:289301.

7. Moraes RR, Faria-e-Silva AL, Ogliari FA, Correr-Sobrinho L, Demarco FF, Piva E. Impact of immediate and delayed light activation on selfpolymerization of dual-cured dental resin luting agents. Acta Biomater 2009;5:2095-2100.

8. Faria-e-Silva AL, Peixoto AC, Borges MG, Menezes M de S, Moraes RR. Immediate and delayed photoactivation of self-adhesive resin cements and retention of glass-fiber posts. Braz Oral Res 2014;28:1-6.

9. Macedo VC, Souza NA, Faria e Silva AL, Cotes C, Silva C, Martinelli M, 
et al.. Pullout bond strength of fiber posts luted to different depths and submitted to artificial aging. Oper Dent 2013;38:E1-E6.

10. Moraes RR, Boscato N, Jardim PS, Schneider LF. Dual and self-curing potential of self-adhesive resin cements as thin films. Oper Dent 2011;36:635-642.

11. Bergoli CD, Amaral M, Boaro LC, Braga RR, Valandro LF. Fiber post cementation strategies: effect of mechanical cycling on push-out bond strength and cement polymerization stress. J Adhes Dent 2012;14:471478.

12. Soares CJ, Pizi EC, Fonseca RB, Martins LR. Influence of root embedment material and periodontal ligament simulation on fracture resistance tests. Braz Oral Res 2005;19:11-16.

13. Sousa Menezes M, Queiroz EC, Soares PV, Faria-e-Silva AL, Soares CJ, Martins LR. Fiber post etching with hydrogen peroxide: effect of concentration and application time. J Endodont 2011;37:398-402.

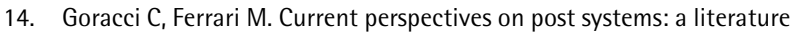
review. Aust Dent J 2011;56:77-83.

15. Mosharraf R, Ranjbarian P. Effects of post surface conditioning before silanization on bond strength between fiber post and resin cement. J Adv Prosthodont 2013;5:126-132.

16. Ebrahimi SF, Shadman N, Nasery EB, Sadeghian F. Effect of polymerization mode of two adhesive systems on push-out bond strength of fiber post to different regions of root canal dentin. J Dent Res 2014;11:32-38.

17. Reginato $\mathrm{CF}$, Oliveira AS, Kaizer MR, Jardim PS, Moraes RR. Polymerization efficiency through translucent and opaque fiber posts and bonding to root dentin. J Prosthodont Res 2013;57:20-23.

18. Santos Alves Morgan LF, Peixoto RT, Castro Albuquerque R, Santos Correa MF, Abreu Poletto LT, Pinotti MB. Light transmission through a translucent fiber post. J Endodont 2008;34:299-302.

19. Faria-e-Silva AL, Fabiao MM, Arias VG, Martins LR. Activation mode effects on the shear bond strength of dual-cured resin cements. Oper Dent 2010;35:515-521.

20. Soares $C J$, Valdivia $A D$, da Silva GR, Santana FR, Menezes M de $S$. Longitudinal clinical evaluation of post systems: a literature review. Braz Dent J 2012;23:135-140.

21. Gomes GM, Gomes OM, Reis A, Gomes JC, Loguercio AD, Calixto AL. Regional bond strengths to root canal dentin of fiber posts luted with three cementation systems. Braz Dent J 2011;22:460-467.

Received September 27, 2014 Accepted December, 15, 2014 